\title{
Residents Post-Occupancy Evaluation of Social Housing in Liberia
}

\author{
Jacob Arku Ziama, Bo Li \\ Department of Architecture and Civil Engineering, Liaoning Technical University, Fuxin, China \\ Email: jakezee92@gmail.com,lntu.libo@qq.com
}

How to cite this paper: Ziama, J.A. and Li, B. (2018) Residents Post-Occupancy Evaluation of Social Housing in Liberia. Journal of Building Construction and Planning Research, 6, 1-22. https://doi.org/10.4236/jbcpr.2018.61001

Received: January 22, 2018

Accepted: March 28, 2018

Published: March 31, 2018

Copyright $\odot 2018$ by authors and Scientific Research Publishing Inc. This work is licensed under the Creative Commons Attribution International License (CC BY 4.0).

http://creativecommons.org/licenses/by/4.0/

(c) (i) Open Access

\begin{abstract}
This paper evaluates the livability and convenience of social housing in Liberia from the residents' perspectives. Using residents' appraisal from several social housing projects in the suburb of Monrovia, residents' satisfaction index with regards to the aesthetic, durability and comfort of their homes were measured. It also assessed their overall living environment which includes access to road and basic service facilities such as hospitals, schools, shopping and recreational centers. How secured and comfortable do they feel within their homes? What are the driving factors that led them to acquire their homes? Data were collected from 662 household heads from three housing estates in the suburb of Monrovia using the stratified systematic sampling method and analyzed using IBM SPSS descriptive statistic. Results show that while occupants of public housing are satisfied with certain aspects of their homes, they are generally unsatisfied with their living environment. This investigation is detailed to inform architects, designers and policymakers' decisions toward social housing in Liberia. It looks at the underlining challenges affecting the improvement of social housing from the end users' perspective and how these challenges can be mitigated to meet consumers' satisfaction and make them part of the design process and policymaking.
\end{abstract}

\section{Keywords}

Residents' Perception, Evaluation, Social Housing, Indoor Environmental Quality, Outdoor Environmental Quality, Liberia

\section{Introduction}

Shelter is an integral part of human existence and the development of any society. The history and importance of shelter are as old as the existence of humankind. According to [1] shelter is universally acknowledged as the second most 
essential human need after food and is considered a significant economic asset in any nation. The importance of shelter and how it separates people into groups needs no further elaboration [2]. According to [3] the lack of adequate housing has made people forced to live in conditions that constitute an affront to human dignity. [4] enlightens the issue of considering housing condition as a social-economic indicator of urban poverty.

Like every other aspect of civilization, shelter has continued to evolve with time to meet up with changing demand. In today's complex and fast-changing world, shelters do not only serve as a place to keep us safe from unfavorable weather conditions but an area that provides us with the necessary comfort and convenience; a place that inspires us and makes our lives healthier and productive. That is why the need for a well-designed shelter to meet our growing needs is paramount to our time and age.

A well-designed building is one that is functional, aesthetic and structurally sound. It is a building that gives more than what has been requested while utilizing limited resources.

The need for Architects/designers to consider the end users of their products (the buildings or other facilities) has not been fully actualized as compare to other industries where consumer experience is the primary driving force.

As stated by [5] buildings are constructed and managed based on standards and specifications established by the government, professionals, and experts who are supposed to have adequate knowledge of user needs and expectations, however, these standards and specifications do not conform to the changing needs and expectations of users. Therefore, building performance can be enhanced by regular performance evaluation, exploring and understanding user needs, hopes, and aspirations.

Over the years, most Architects/Designers have spent a considerable amount of their time striving to showcase their creativity and ingenuity and paying very little attention to the user experience of their work. According to [6] post-occupancy evaluation is still an emerging discipline, and furthermore an obscure part of the design cycle. POE, in general, is the concern of a somewhat limited number of architects. Post-occupancy evaluation has been an even more elusive undertaking in the design cycle, not only because it is beyond the direct responsibility of the design architect but also because the post-occupancy evaluation task requires expertise other than design [6]. Traditionally, success in the construction sector has been measured by cost, quality, time and scope; many times a project is considered successful if the work is delivered within the deadline, budget and according to specification [7]; thereby, disregarding occupants' experience.

Rather than designing for the consumer, most architects and designers should begin to look at design from the users' perspective and start to plan with the consumers instead of for the consumers.

However, building evaluation work does not fit long-standing classifications; it spans the professions (architecture, services engineering and facilities man- 
agement being the most prominent). It is multidisciplinary, often to a confusing extent (design, psychology, economics, planning, sociology, and engineering). It draws on laboratory research and physical measurement, but it is predominantly about empirical field work, visiting and studying real buildings in use and talking to real people [8].

Social housing in Liberia has not received much attention over the years leaving many citizens with the daunting task of undertaking their own construction projects to cater to their housing needs with little or no regulation from the government. This passive behavior toward social housing has led to the proliferation of sprawl and slums in most of the country leaving most citizens to live in unhealthy, unstructured, unsecured and inaccessible communities. The need to address this situation cannot be overemphasized and has laid the basis upon which this research is conducted. It investigates the performance of public housing to understand why most citizens are not attracted to public housing instead choose to undertake their own construction.

According to [9] POE is the collection and review of user satisfaction, space utilization, and resource consumption of a completed constructed facility after occupation to identify important occupant and building issues. This information can help architect, designers, and policymakers adequately mitigate these issues in future construction to provide a much better user experience.

Because our health and well-being depend on the serenity of our environment, this study aim at evaluating users' experience of public housing in Liberia and formulates realistic solutions to improve user experience and their health and well-being.

Many problems arising from the use of public housing are those of deficiency in the performance of buildings after its occupation. Such problems include performance and functional efficiency of the building, accessibility, distribution, and configuration of spaces. It also includes access to primary services (schools, hospital, shopping and recreational centers); spatial arrangement, indoor environment quality (ventilation, day-lighting, thermal comfort, and productivity) outdoor environmental quality; and the safety and security of life and properties. The need for a systematic and synergetic approach to alleviate these problems cannot be overemphasized. The primary and most significant step in this process is to understand the problem from the user perspective holistically; through a well-coordinated Post-Occupancy Evaluation POE. Architect, designer, developers and government regulator should have a better understanding of how buildings are performing when providing service to occupants. Comparing a building in use to their design intention can provide useful feedback to guide future design decision [10].

Some other benefits that come with POE are the recognition of functional design features that can be scrutinized recurrently. These include identification of problems to mitigate or reduce building or facilities defect, identification of building performance and environment, identification of redundant and unnecessary building features, and empowerment of user to negotiate building issues 
and reduce maintenance work and cost [9].

In recent times, much research has been done on POE gear toward informing designers and architects decision and improving users' experience. However, this research investigates user experience of public housing in Liberia explicitly and seeks to understand and mitigate some of the challenges users of public housing faced.

\section{Methodology}

With user experience at the core of this research, the study was conducted using user survey questioners, physical building assessment, and personal interviews to gather firsthand information about user's experience of public housing in the suburb of Monrovia. The survey was conducted over a period of three months September 2017 to December 2017, with the assistance of haired survey assistants.

All of the sampling houses in this study were constructed by the government of Liberia through hire contractors for low to middle-income earners during the period 2006 to 2017. Using the stratified systematic sampling method, a total of 800 units (two and three bedrooms) from three housing estates located in Brewerville, Fendall and Schiefflin Town were selected for this study. Household heads were selected as our primary informants, and due to most household heads busy schedule, visits, assessments, and interviews were mostly scheduled for weekends morning when they were most likely home.

A total of 800 survey questionnaires were issued out to household heads, and a physical assessment of their homes was done along with personal interviews. The questionnaires cover several areas including general information about the occupants, their experiences with several aspects of their homes including spatial arrangement, indoor aesthetic and environmental qualities; outdoor aesthetic and environmental qualities; along with structural and safety issues. For detail about the questionnaire, please see Appendix 1. The physical assessments assessed the buildings layout, materials used for construction including walls, doors, windows, ceiling, and roofing, along with their current conditions as well as structural integrity and safety features. For detail about building physical assessment, please see Appendix 2. The personal interviews were to gather further information from the occupants about their experiences with their living environment.

Of the 800 questionnaires issued, 662 representing $82.75 \%$ were successfully returned and considered for sampling using IBM SPSS statistical analysis software.

During the sampling data collected were subjected to descriptive analysis to determine the frequencies, percentage of the respondents' personal information provided including gender, age, level of education, sectors of employment and range of income. The Sum of individual respondent's satisfaction score on all of the building attribute which is the Individual Satisfaction score (ISS) was extracted from the descriptive analysis. The average satisfaction score that was 
given by all respondents on all of the building attributes which is the Mean Satisfaction Score (MSS) was also extracted. Also, the sum of actual satisfaction score on the five-point Likert scale given by all the respondents on each building attribute which is Relative Performance Index (RPI) was also extracted from the descriptive analysis.

While ISS is an expression of the respondent's satisfaction with all of the building attributes put together, MSS is the average satisfaction score given by all respondents on each of the attributes. RPI is computed as the sum of the actual satisfaction score on the five-point Likert scale given by all the respondents on each building attribute as a proportion of the sum of maximum possible satisfaction score on the five-point Likert scale that all the respondents could give on each of the building attributes. The RPI is taken as a measure of the relative contribution or importance of each building attribute towards enhancing the activities and well-being of the residents.

\section{Results}

\subsection{Occupants' General Information}

After running a descriptive analysis of the information collected from our respondents, the result shows that $74.9 \%$ are males while $25.1 \%$ are females. This result was anticipated as evident by [11] Gender Economic participation and opportunity ranking, Liberia rank 114 among 144 countries in the world. The report indicates that there is a gender gap in income earnings and opportunity in most African countries where males tend to dominate the income earnings while most female partners are left with domestic work thereby disenfranchising them from owning properties. This gap could also be because principal respondents are household heads and males tend to be the head of the home. Therefore, this result does not indicate if the husband and his wife contributed to purchased their home.

While it was not prudent to ascertain the exact ages of our principal respondents, the result shows that $35 \%$ are between the ages of $46-60$ years. While $29 \%$ are between the ages of $36 \%-45 \%, 17.2 \%$ are between the ages of $26-35$ years, $16.8 \%$ are above 60 , and $2 \%$ are between the ages $18-25$ years. This result is because most of the homes that were investigated, were constructed during 2006-2017 and most of those who could afford to acquire during this time were those who were actively employed and still in the employment age range as compared to those who were just starting their lives or those who were retired.

It is also observed that $49.7 \%$ of the principal respondents have been living in their homes for 4 - 6 years while 33.7\% have been living in their homes for $7-10$ years and $16.6 \%$ have been living in their homes for $1-3$ years. This pattern shows these houses were constructed in phases over a period of 10 years, therefore leading to gradual acquisition and occupation.

Majority of the respondents $55.6 \%$ are married, $11 \%$ are divorced, $22.1 \%$ are unmarried, and $11.3 \%$ are widowed. Result also shows $74.2 \%$ have obtained their 
Bachelor's degrees, $18.45 \%$ have obtained their Master's degrees, $6.2 \%$ have obtained their Ph.D. degrees and 1.2\% are holders of high school diplomas. Of this amount, $71.6 \%$ are employed in the public sector while those employed in the private sector are $28.4 \%$. This result shows the government constructed these houses for low and middle-income earners and the government is the highest employer in the country. Therefore, it is expected that a majority of those who can afford to acquire a home are within the employed of the government.

Also, $67.7 \%$ of the houses are 2-bedroom, and 32.3\% are 3-bedroom with $54.1 \%$ of them having more than four occupants, $21.8 \%$ having four occupants, $14.55 \%$ having three occupants, $6.6 \%$ having two occupants and $3 \%$ having one occupant. This result coincides with the fact that most African families are large and accommodating distance relatives is a norm in most African societies.

As obtaining the exact earning of the respondents was not feasible. The result shows that $34.7 \%$ of the principal respondents are earning between USD 201 to $500,24.8 \%$ are earning $501-1000,18.6 \%$ are earning $1001-2000,11.8 \%$ are earning 101 - 200, and 10.1\% are earning above 2000. This result coincides with the fact that these houses were constructed for low and middle-income earners. This result shows why $57.6 \%$ are paying mortgages on their homes, only $19.65 \%$ own their homes, $10.6 \%$ are renting, $8.6 \%$ have a short-term lease, and $4.1 \%$ have a long-term lease. Price was the primary reason that influenced $58.6 \%$ of the respondent's purchase. Those influenced by the location of the property were 20.4\%; while those influenced by the spatial arrangement of the property were $12.5 \%$. Additionally, those influenced by the quality of the property were $3.5 \%$; and those influenced by the aesthetic appearance of the property were $5 \%$.

\subsection{Buildings Physical Characteristics}

From the physical assessment done on these buildings, it is evident that they were constructed using conventional building materials (Blocks, Bricks, Mortar, timber, steel, sand, glass, aluminum and corrugated roofing sheets) found on the local market. The physical assessment shows they are structurally sound which speaks to the fact that they were recently constructed and adequately supervised by the requisite government agency responsible for public housing construction. Table 1 show details obtained from the physical assessment of the houses under investigation.

Table 1 shows that most of the buildings $47.1 \%$ are 2-bedroom single family bungalow constructed with hollow masonry block as the predominant wall material plaster with mortar and covered with enamel paint covering. $72.1 \%$ of the windows are sliding glass aluminum windows, $73.4 \%$ of the homes have exterior steel doors and interior plywood doors. $94.7 \%$ of the homes have burglar bars on their windows. Most of the buildings are relatively in good structural and physical condition and are well kept by the occupants. While the layout of the buildings is well planned, there are not sufficient green spaces for occupant despite the lack of public parks. These housing estates also lack proper storm water 
Table 1. Buildings physical characteristics.

\begin{tabular}{|c|c|c|c|}
\hline \multicolumn{4}{|c|}{ Buildings physical characteristics } \\
\hline No. & Characteristics & Frequency $(N=662)$ & Percentage \\
\hline 1.0 & Building Topology & & \\
\hline 1.1 & Single-family bungalow & 312 & 47.1 \\
\hline 1.2 & Semidetached bungalow & 205 & 31 \\
\hline 1.3 & Duplex & 123 & 18.6 \\
\hline 1.4 & Triplex & 22 & 3.3 \\
\hline 2.0 & Number of bedrooms in the building & & \\
\hline 2.1 & Two bedrooms & 448 & 67.7 \\
\hline 2.2 & Three bedrooms & 214 & 32.3 \\
\hline 3.0 & Building wall material & & \\
\hline 3.1 & Refractory bricks & 25 & 3.8 \\
\hline 3.2 & Compressed laterite bricks & 285 & 43 \\
\hline 3.3 & Hollow sandcrete blocks & 352 & 53.2 \\
\hline 4.0 & Wall covering material & & \\
\hline 4.1 & Refractory bricks finish & 25 & 3.8 \\
\hline 4.2 & Compressed laterite bricks finish & 285 & 43 \\
\hline 4.3 & Mortar screening Enamel paint covering & 352 & 53.2 \\
\hline 5.0 & Window type & & \\
\hline 5.1 & Sliding glass & 477 & 72.1 \\
\hline 5.2 & Jalousie & 185 & 27.9 \\
\hline 6.0 & Door type & & \\
\hline 6.1 & Steel door exterior, timber door interior & 112 & 16.9 \\
\hline 6.2 & Steel door exterior, plywood door interior & 486 & 73.4 \\
\hline 6.2 & Timber door exterior, plywood door interior & 64 & 9.7 \\
\hline 7.0 & Availability of insect screen & & \\
\hline 7.1 & Yes & 634 & 95.8 \\
\hline 7.2 & No & 28 & 4.2 \\
\hline 8.0 & Availability of burglar bars on the window & & \\
\hline 8.1 & Yes & 627 & 94.7 \\
\hline 8.2 & No & 35 & 5.3 \\
\hline 9.0 & Floor finish material & & \\
\hline 9.1 & Porcelain tiles & 101 & 15.3 \\
\hline 9.2 & Ceramic tiles & 516 & 77.9 \\
\hline 9.3 & Vinyl tiles & 45 & 6.8 \\
\hline 10.0 & Ceiling material & & \\
\hline 10.1 & Plaster of Paris (POP) screened & 18 & 2.7 \\
\hline 10.2 & Painted hard board & 451 & 68.2 \\
\hline 10.3 & Painted plywood & 169 & 25.5 \\
\hline 10.4 & Acoustic & 24 & 3.6 \\
\hline
\end{tabular}




\section{Continued}

\begin{tabular}{lccc}
\hline 11.0 & Roof covering material & & \\
\hline 11.1 & Galvanize roofing sheets & 335 & 50.6 \\
11.2 & Aluminum roofing sheets & 267 & 40.3 \\
11.3 & Long span aluminum roofing sheets & 25 & 3.8 \\
11.4 & Roofing tiles & 35 & 5.3 \\
\hline 12.0 & House condition & & \\
\hline 12.1 & Excellent & 66 & 10 \\
12.2 & Good & 344 & 52 \\
12.3 & Needs manor repair & 156 & 23.6 \\
12.4 & Needs repair & 80 & 12 \\
12.5 & Needs major repair & 16 & 2.4 \\
\hline 13.0 & Building layout condition & & 66.6 \\
\hline 13.1 & Well planned & 441 & 33.4 \\
13.3 & Properly layout & 221 & \\
\hline 14.0 & Sanitary condition & 36 & 5.4 \\
\hline 14.1 & Excellent & 382 & 29 \\
14.2 & Good & 192 & 7.9 \\
14.3 & Satisfactory & 52 & \\
14.4 & Fair & & \\
\hline
\end{tabular}

drainages for the collection and discharge of runoff water thereby causing fear of flood for residents during the torrential raining season. Because these physical assessments were conducted during the dry season, a substantial residue of dust was observed on the exterior walls, windows, and furniture of most of these homes due to unpaved roads.

Figure 1 shows a floor plan of the 2-bedroom single family bungalow and Figure 2 shows the floor plan of the 3-bedroom single family bungalow, two of the housing types under investigation. It can be observed from the plan that the total floor areas of the buildings are $104.37 \mathrm{~m}^{2}$ and $158.17 \mathrm{~m}^{2}$ respectively. The minimum bedroom size is $13.18 \mathrm{~m}^{2}$ and a living and dining room area of more than $26 \mathrm{~m}^{2}$. This configuration of space explains why $31.7 \%$ and $49.8 \%$ of the respondents are very satisfied and satisfied respectively with their bedroom size while $29.8 \%$ and $50.2 \%$ are very satisfied and satisfied respectively with their living area size as shown in Table 2. It is also evident from Figure 1 that all of the bedrooms have two windows each that enable proper cross ventilation which explains while $23.60 \%$ and $40.80 \%$ of the respondents are very satisfied and satisfied respectively with the Natural ventilation in their building. However, respondents are not satisfied with the overall aesthetic of their homes.

\subsection{Occupants' Satisfaction and Building Performance}

As shown in Table 3, nineteen building attributes with MSS between 4.00 and 3.00 are contributing significantly to the overall needs of occupants. Seven 


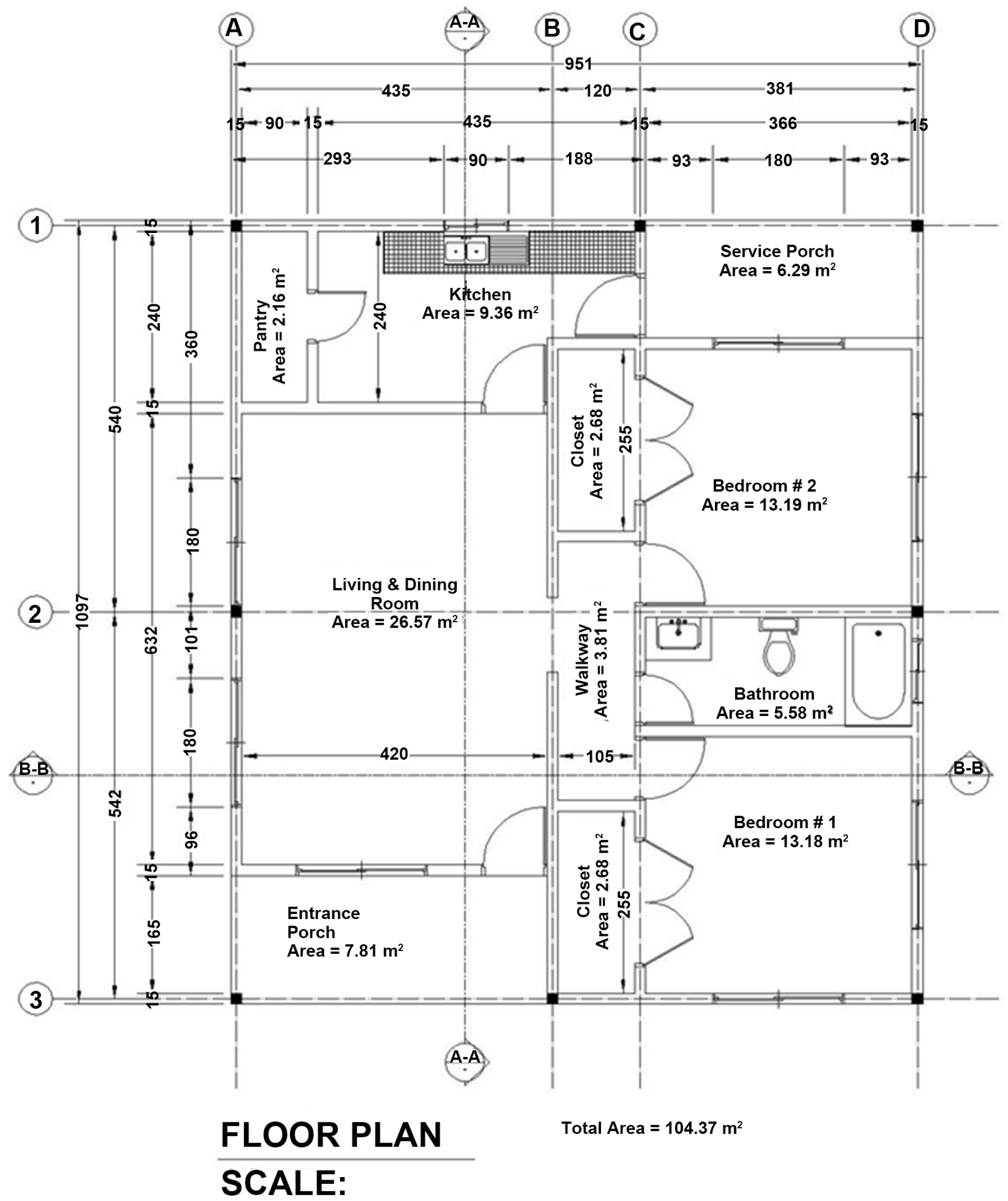

Figure 1. Typical floor plan of the 2-Bedroom single family Bungalow.

building attributes with MSS between 2.88 and 2.50 are contributing averagely to the overall needs of occupants and eleven attributes with MSS between 2.41 and 1.65 are contributing negligibly to the overall needs of the occupants. The average MSS is 2.89 which show residents are not satisfied with their living 


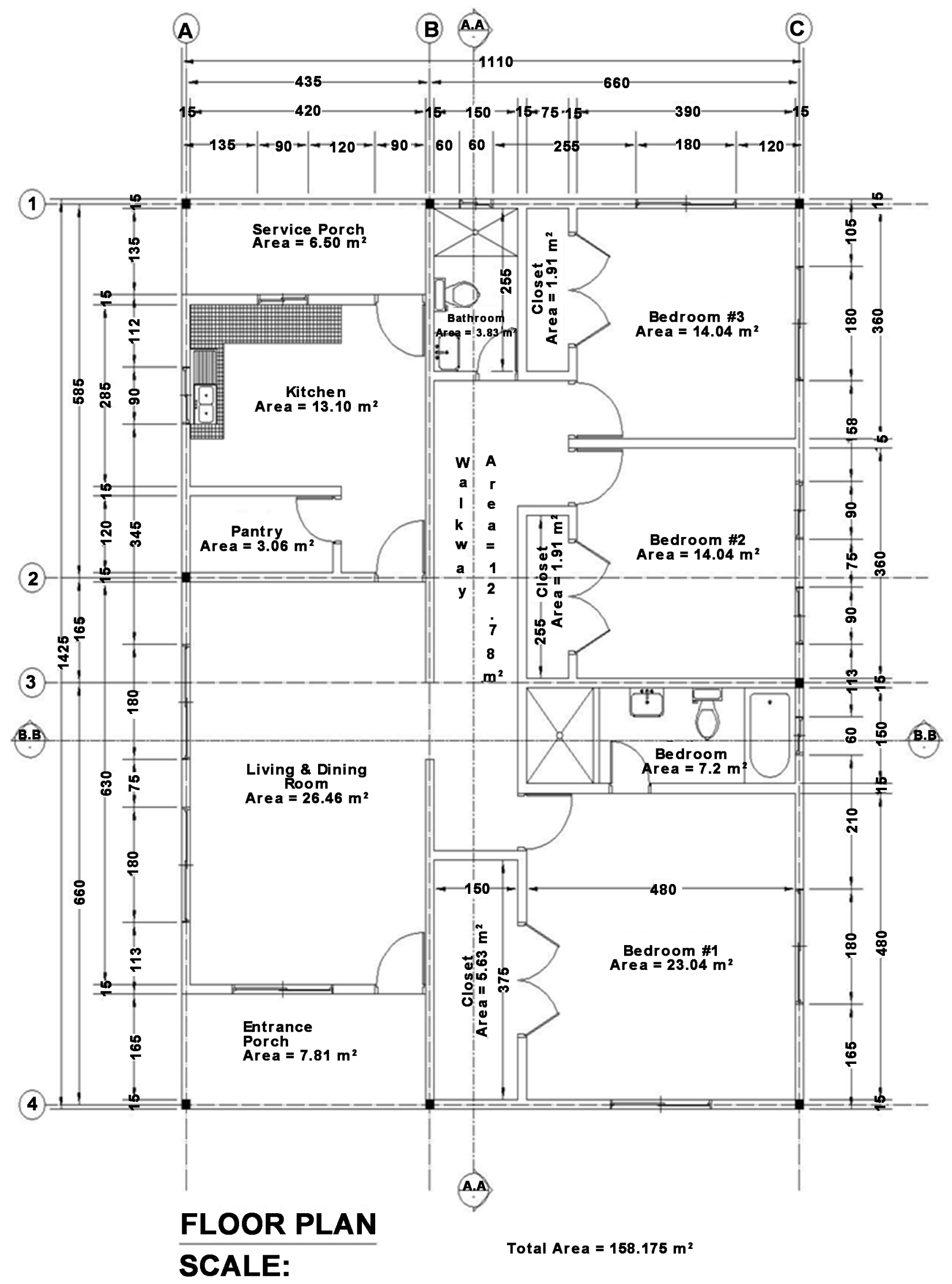

Figure 2. Typical floor plan of the 3-Bedroom single family Bungalow. 
Table 2. Residents' satisfaction with their home.

\begin{tabular}{|c|c|c|c|c|c|c|c|c|c|c|c|}
\hline & \multirow{3}{*}{ Building components } & \multicolumn{10}{|c|}{ Scores } \\
\hline & & \multicolumn{2}{|c|}{ Very Unsatisfied } & \multicolumn{2}{|c|}{ Unsatisfied } & \multicolumn{2}{|c|}{ Nature } & \multicolumn{2}{|c|}{ Satisfied } & \multicolumn{2}{|c|}{ Very satisfied } \\
\hline & & Frequency & Percent & Frequency & Percent & Frequency & Percent & Frequency & Percent & Frequency & Percent \\
\hline 1 & Bedrooms size & 21 & 3.20 & 93 & 14.09 & 8 & 1.21 & 330 & 49.80 & 210 & 31.70 \\
\hline 2 & Bedrooms location & 32 & 4.80 & 115 & 17.39 & 12 & 1.81 & 291 & 44.00 & 212 & 32.00 \\
\hline 3 & Living area size & 21 & 3.20 & 101 & 15.14 & 11 & 1.66 & 332 & 50.20 & 197 & 29.80 \\
\hline 4 & Living area location & 35 & 5.30 & 107 & 16.19 & 14 & 2.11 & 326 & 49.20 & 180 & 27.20 \\
\hline 5 & Service area size & 30 & 4.50 & 121 & 18.29 & 6 & 0.91 & 402 & 60.70 & 103 & 15.60 \\
\hline 6 & Service area location & 12 & 1.80 & 86 & 13.04 & 13 & 1.96 & 413 & 62.40 & 138 & 20.80 \\
\hline 7 & $\begin{array}{l}\text { Building overall } \\
\text { layout }\end{array}$ & 8 & 1.20 & 82 & 12.43 & 21 & 3.17 & 445 & 67.20 & 106 & 16.00 \\
\hline 8 & $\begin{array}{l}\text { Building floor to } \\
\text { ceiling height }\end{array}$ & 334 & 50.50 & 242 & 36.44 & 9 & 1.36 & 72 & 10.90 & 5 & 0.80 \\
\hline 9 & $\begin{array}{l}\text { Building capacity to } \\
\text { meet occupants needs }\end{array}$ & 36 & 5.40 & 82 & 12.47 & 26 & 3.93 & 314 & 47.40 & 204 & 30.80 \\
\hline 10 & Building Privacy level & 20 & 3.00 & 74 & 11.28 & 22 & 3.32 & 318 & 48.00 & 228 & 34.40 \\
\hline 11 & $\begin{array}{l}\text { Building interior } \\
\text { aesthetic }\end{array}$ & 117 & 17.70 & 334 & 50.48 & 18 & 2.72 & 151 & 22.80 & 42 & 6.30 \\
\hline 12 & $\begin{array}{l}\text { Building overall } \\
\text { comfort level }\end{array}$ & 30 & 4.50 & 147 & 22.17 & 24 & 3.63 & 407 & 61.50 & 54 & 8.20 \\
\hline 13 & $\begin{array}{c}\text { Flow of natural light } \\
\text { in building }\end{array}$ & 18 & 2.70 & 152 & 23.03 & 19 & 2.87 & 418 & 63.10 & 55 & 8.30 \\
\hline 14 & $\begin{array}{l}\text { Artificial lighting in } \\
\text { building }\end{array}$ & 48 & 7.30 & 258 & 38.92 & 27 & 4.08 & 301 & 45.50 & 28 & 4.20 \\
\hline 15 & $\begin{array}{c}\text { Natural ventilation in } \\
\text { building }\end{array}$ & 18 & 2.70 & 202 & 30.48 & 16 & 2.42 & 270 & 40.80 & 156 & 23.60 \\
\hline 16 & $\begin{array}{l}\text { Texture of walls, } \\
\text { ceilings and floors }\end{array}$ & 65 & 9.80 & 424 & 64.06 & 36 & 5.44 & 113 & 17.10 & 24 & 3.60 \\
\hline 17 & $\begin{array}{l}\text { Bathroom and } \\
\text { kitchen fixtures }\end{array}$ & 28 & 4.20 & 267 & 40.36 & 38 & 5.74 & 329 & 49.70 & 0 & 0.00 \\
\hline 18 & $\begin{array}{l}\text { Option to control } \\
\text { indoor temperature }\end{array}$ & 150 & 22.70 & 455 & 68.73 & 23 & 3.47 & 34 & 5.10 & 0 & 0.00 \\
\hline 19 & $\begin{array}{l}\text { Regular smell in } \\
\text { building }\end{array}$ & 287 & 43.40 & 0 & 0.00 & 31 & 4.68 & 317 & 47.82 & 27 & 4.10 \\
\hline 20 & $\begin{array}{l}\text { Option to control } \\
\text { noise transmission } \\
\text { into the building }\end{array}$ & 215 & 32.50 & 336 & 50.71 & 37 & 5.59 & 74 & 11.20 & 0 & 0.00 \\
\hline 21 & Plumbing work & & & 257 & 38.80 & 48 & 7.30 & 321 & 48.50 & 36 & 5.40 \\
\hline 22 & Outdoor air quality & 18 & 2.70 & 387 & 58.46 & 42 & 6.34 & 194 & 29.30 & 21 & 3.20 \\
\hline 23 & Waste disposal & 15 & 2.30 & 260 & 39.32 & 33 & 4.98 & 330 & 49.80 & 24 & 3.60 \\
\hline 24 & Exterior aesthetic & 73 & 11.00 & 319 & 48.25 & 52 & 7.85 & 161 & 24.30 & 57 & 8.60 \\
\hline 25 & $\begin{array}{l}\text { Runoff water } \\
\text { collection and } \\
\text { disposal }\end{array}$ & 195 & 29.50 & 354 & 53.37 & 24 & 3.63 & 60 & 9.10 & 29 & 4.40 \\
\hline 26 & $\begin{array}{l}\text { Space between } \\
\text { buildings }\end{array}$ & 9 & 1.40 & 427 & 64.41 & 37 & 5.59 & 168 & 25.40 & 21 & 3.20 \\
\hline
\end{tabular}




\section{Continued}

\begin{tabular}{|c|c|c|c|c|c|c|c|c|c|c|c|}
\hline 27 & Green space & 76 & 11.50 & 421 & 63.57 & 32 & 4.83 & 133 & 20.10 & 0 & 0.00 \\
\hline 28 & $\begin{array}{c}\text { Access to basic } \\
\text { services }\end{array}$ & 316 & 47.70 & 232 & 35.10 & 51 & 7.70 & 63 & 9.50 & 0 & 0.00 \\
\hline 29 & Access to electricity & 297 & 44.90 & 328 & 49.54 & 9 & 1.36 & 28 & 4.20 & 0 & 0.00 \\
\hline 30 & $\begin{array}{l}\text { Access to water } \\
\text { supply }\end{array}$ & 184 & 27.80 & 453 & 68.44 & 7 & 1.06 & 18 & 2.70 & 0 & 0.00 \\
\hline 31 & Road access & 61 & 9.20 & 473 & 71.49 & 12 & 1.81 & 116 & 17.50 & 0 & 0.00 \\
\hline 32 & Security in building & 74 & 11.20 & 339 & 51.19 & 14 & 2.11 & 198 & 29.90 & 37 & 5.60 \\
\hline 33 & $\begin{array}{l}\text { Option to escape fire } \\
\text { emergency }\end{array}$ & 150 & 22.70 & 334 & 50.42 & 25 & 3.78 & 153 & 23.10 & 0 & 0.00 \\
\hline 34 & $\begin{array}{l}\text { Building capacity to } \\
\text { prevent break-in }\end{array}$ & 60 & 9.10 & 169 & 25.58 & 16 & 2.42 & 375 & 56.60 & 42 & 6.30 \\
\hline 35 & $\begin{array}{l}\text { Building capacity to } \\
\text { keep insects out }\end{array}$ & 36 & 5.40 & 174 & 26.39 & 6 & 0.91 & 410 & 61.90 & 36 & 5.40 \\
\hline 36 & $\begin{array}{l}\text { Building capacity to } \\
\text { withstand flood }\end{array}$ & 92 & 13.90 & 301 & 45.45 & 46 & 6.95 & 163 & 24.60 & 60 & 9.10 \\
\hline 37 & Electrical works & 66 & 10.00 & 287 & 43.32 & 29 & 4.38 & 218 & 32.90 & 62 & 9.40 \\
\hline \multicolumn{2}{|c|}{ Average score } & & 13.26 & 248 & 37.53 & 24 & 3.65 & 237 & 35.78 & 64 & 9.63 \\
\hline
\end{tabular}

environment. Table 2 shows $13.26 \%$ of the respondents are very unsatisfied with their dwelling place while $37.53 \%$ are unsatisfied, $35.78 \%$ are satisfied, $9.63 \%$ are very satisfied with their dwelling place and $3.65 \%$ of the respondents have nurture feeling about their home. Mainly, respondents are more satisfied with the level of privacy and the general building layout which includes bedrooms' sizes and locations, living area size and location, service area size and location. They are also satisfied with the overall indoor environment quality and comfort of their homes. Basically among their satisfaction are the flow of natural light across their homes, natural ventilation across their homes, regular smell in their homes and disposal of solid and liquid waste from their homes. Even though they had dissatisfaction about the insufficient floor to ceiling height, option to control noise transmission in their homes and option to control indoor temperature.

Respondents are mostly unsatisfied with the interior and exterior aesthetic of their homes including the texture and appearance of their walls, floor, and ceiling which explains why the aesthetic of their home influenced only $5 \%$ of the respondent's purchase. Like [12] notice in Malaysia, this could be the result of shoddy artistry in the finishing work. Most building technicians are not formally trained and lack the skills to perform these tasks flawlessly.

Even though most of the homes surveyed have exterior steel doors and burglar bars, most respondents do not feel safe in their homes due to the lack of electricity. Access to electricity, water supply, and basic services score the least MSS as shown in Table 3. 
Table 3. Building attributes mean satisfaction scores and relative performance indices.

\begin{tabular}{|c|c|c|c|c|}
\hline \multicolumn{5}{|c|}{$\begin{array}{l}\text { Mean Satisfaction scores and relative performance indices of RPIs } \\
\text { (in descending order of importance). }\end{array}$} \\
\hline No. & Building attributes & MSS & ASSac & RPIa \\
\hline 1 & Building privacy level & 4.00 & 2646 & 0.799 \\
\hline 2 & Bedrooms size & 3.93 & 2601 & 0.786 \\
\hline 3 & Living area size & 3.88 & 2569 & 0.776 \\
\hline 4 & Service area location & 3.87 & 2565 & 0.775 \\
\hline 5 & Building capacity to meet occupants needs & 3.86 & 2554 & 0.772 \\
\hline 6 & Building overall layout & 3.84 & 2545 & 0.769 \\
\hline 7 & Bedrooms location & 3.81 & 2552 & 0.762 \\
\hline 8 & Living area location & 3.77 & 2495 & 0.754 \\
\hline 9 & Service area size & 3.65 & 2413 & 0.729 \\
\hline 10 & Natural ventilation in building & 3.52 & 2330 & 0.704 \\
\hline 11 & The flow of natural light in the building & 3.52 & 2327 & 0.703 \\
\hline 12 & Building overall comfort level & 3.47 & 2294 & 0.693 \\
\hline 13 & Building capacity to prevent insects entry & 3.36 & 2222 & 0.671 \\
\hline 14 & Building capacity to withstand break-in & 3.26 & 2156 & 0.651 \\
\hline 15 & Plumbing works & 3.21 & 2122 & 0.641 \\
\hline 16 & Regular smell in building & 3.13 & 2070 & 0.625 \\
\hline 17 & Waste disposal & 3.13 & 2074 & 0.627 \\
\hline 18 & Bathrooms and kitchens fixtures & 3.01 & 1992 & 0.602 \\
\hline 19 & Artificial lighting in building & 3.00 & 1989 & 0.601 \\
\hline 20 & Electrical works in building & 2.88 & 1909 & 0.577 \\
\hline 21 & Outdoor air quality & 2.72 & 1799 & 0.544 \\
\hline 22 & Exterior aesthetic & 2.71 & 1796 & 0.543 \\
\hline 23 & Building capacity to withstand flood & 2.69 & 1784 & 0.539 \\
\hline 24 & Security in building & 2.68 & 1771 & 0.535 \\
\hline 25 & Space between buildings & 2.65 & 1751 & 0.529 \\
\hline 26 & Building interior aesthetic & 2.50 & 1653 & 0.499 \\
\hline 27 & The texture of walls, floors, and ceilings & 2.41 & 1593 & 0.481 \\
\hline 28 & Provision of green space & 2.34 & 1546 & 0.467 \\
\hline 29 & Road access to the building & 2.28 & 1507 & 0.455 \\
\hline 30 & Option provided to escape fire emergency & 2.27 & 1505 & 0.455 \\
\hline 31 & Runoff water collection & 2.05 & 1360 & 0.411 \\
\hline 32 & Option to control noise transmission in building & 1.95 & 1294 & 0.391 \\
\hline 33 & Option to control indoor temperature & 1.91 & 1265 & 0.382 \\
\hline 34 & Access to water supply & 1.79 & 1183 & 0.357 \\
\hline 35 & Access to basic services & 1.79 & 1185 & 0.358 \\
\hline 36 & Building floor to ceiling height & 1.75 & 1158 & 0.350 \\
\hline 37 & Access to electricity & 1.65 & 1092 & 0.330 \\
\hline
\end{tabular}


While most respondents are satisfied with the privacy level, spatial arrangement, indoor environmental quality and the overall comfort of their homes; the majority of the respondents are frustrated with their access to basic services. Because these housing estates are in the suburb of the city, occupants have to drive for several miles to access basic services such as shopping centers, medical centers, schools and recreational centers.

Respondents are not also satisfied with the road access to their communities something that was evident by several visits made on these roads. With regards to the outdoor environmental quality, most of the respondents interviewed were unsatisfied due to the unpaved road leading to their communities and in their communities. They said due to the tropical climate of the country; they are faced with nearly impossible reads during the raining season and insufficient collection and discharge of runoff water due to the lack of adequate drainage facilities which often leave them with fear of their homes flooding. Moreover, during the dry season, they have to deal with the residue of dust left in their homes settling on walls, windows, and furniture due to unpaved roads in their communities. While these housing estates do not have public parks, results show most of the respondents are not satisfied with the space between their homes and the adjacent homes and that the green spaces provided them are insufficient. As shown in Figure 3, majority of the respondents are not satisfied with their dwellings and will like more to be done to make some improvement.

\section{Conclusions}

Evident by the results gather while residents are satisfied with some aspect of their homes like the privacy level, spatial arrangements and indoor environment quality they are unsatisfied with their living environment. Their dissatisfaction is due to several factors ranging from the look of their homes, low floor to ceiling height; inaccessibility of water, electricity and basic services; poor road access and inadequate drainage system. This result is contrary to that of [10] and [13] were residents of public housing estates in Lagos and Ogun State of Nigeria were satisfied with their living environment. It is also contrary to [14] findings in Kuala Lumpur where building performance criteria highly correlated with the occupants' satisfaction. It also does not correlate with [15] where initial outcomes showed a positive relationship between perceptions and building performance criteria.

As [4] noted the empirical evidence of the relationship between housing conditions and quality of life, it is essential for governmental regulators to put policies into place to ensure communities are adequately planned with adequate road access and access to basic services. The need to ensure the provision of electricity and potable water also needs to be addressed adequately by the government. Despite the presence of steel doors and burglar bars on their homes, occupants do not feel safe in their homes due to the lack of electricity. The problem with roads in these estates also needs to be adequately addressed by the 


\section{Residents satisfaction with their homes}

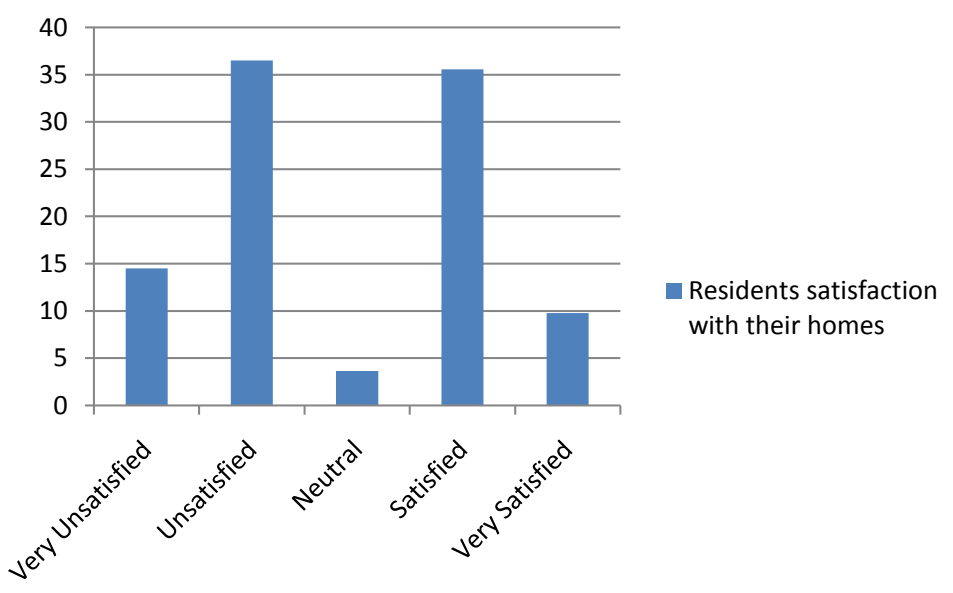

Figure 3. Residents satisfaction with their homes.

government because most residents complain that they are facing severe health problem due to the residue of dust left in their homes during the dry season which also increases the maintenance frequency and cost of their homes.

The need for a social/behavioral design approach as proposed by [6] needs to be considered by Architects, designers and policymakers in Liberia to ensure a healthier and sustainable living environment for the end users.

It is also important to consider the need to train more professionals and technicians in the building industry as it is very vital and critical to the development of the building industry.

Findings show that occupants are not satisfied with their buildings and these buildings are not meeting their overall needs. Basically among residents' dissatisfactions as shown in Table 2 are:

$>$ Option to control noise pollution

$>$ Option to control indoor temperature

$>$ Access to water supply

Access to basic services

Building floor to ceiling height and

Access to electricity

As stated by [16] Government has to stimulate housing development by providing more infrastructures including roads, hospitals, schools, improved water and electricity supply, especially in strategic locations to reduce housing demands in the cities. A study of risk accumulation and reduction in African cities by [17] found that risk in most African cities is not only limited to the proliferation of hazards and vulnerability but also the way in which hazards are created. Notably through urban expansion into exposed locations and through failures in infrastructure provision.

The slow process of urban planning and zoning, in the face of rapid urbanization in most urban centers, has resulted in the poor layout of buildings with in- 
adequate roads between them and inadequate drainage and provision for refuse evacuation. Thus there is a high incidence of pollution (water, solid waste, air, and noise) and inadequacy of open spaces for other land uses [18]. Like [19] emphasized the need for The Malaysian building industry to develop and work towards a more sustainable and green architecture, the Liberian building industry needs to do the same with the government laying a sustainable framework. It is therefore recommended that the government of Liberia develop adequate housing policies with the health and well-being, convenience and productivity, safety and security of occupants as the top priorities. It is also essential for developers to consider accessibility, access to basic services and the provision of potable water and electricity during the initial planning stage of these developments. With these policies and measures in place, it is also prudent to consider training professionals and technicians in the building industry as it was observed occupants' dissatisfaction with the look of their homes was mostly due to shoddy finishing work that was done by building technicians and supervised by building professionals. It is also critical for Architects, designers and policymakers to begin to engage in what [6] calls social/behavioral design approach with occupants experience at the center of the design process, as [6] proposed:

$>$ Design practice should incorporate social design as a complement to the holistic task of architectural practice.

- Social design should be the fundamental task of an architect. The eventual design product should be humane and habitable, serving the goals and objectives of the occupants of a specific built environment.

Accordingly, the architectural education system should break new ground in producing architects with an added value regarding environment-behavior expertise to undertake the tasks of both programming and post-occupancy evaluation.

An even more necessary transformation could be achieved by reducing the enormous gap between the attitudes and values of designers and those of the general public concerning the designs of various facilities.

The sampling in this study is from three housing estates in the suburb of Monrovia that were constructed between 2006 and 2017 and should not represent the entire public housing sector in Liberia; it is essential that further extensive research be conducted to ascertain a broader user perception of public housing in Liberia. Further research also needs to look at the energy efficiency, sustainability, and maintenance frequency and cost to occupants.

\section{Acknowledgements}

This work would not have been made possible without the resourceful guidance of our hard-working support team at Liaoning Technical University. These selfless individuals have worked courageously to ensure we are prepared to face the prevailing challenges of our time. The academic and moral support received from these great minds, brought this work to fruition. Our heartfelt gratitude 
goes to the Office for International Exchange and Cooperation at Liaoning Technical University for providing the academic environment under which this work was made possible. Most importantly, we are grateful to the governments of The People's Republic of China and The Republic of Liberia for providing the platform upon which this work was made possible. To our families and friends, the moral support provided during the course of this work cannot go un-noticed and will continue to serve as an inspiration for the challenges ahead.

\section{References}

[1] Jiboye, A.D. (2014) Significance of House-Type as a Determinant of Residential Quality in Osogbo, Southwest Nigeria. Frontiers of Architectural Research, 3, 20-27. https://doi.org/10.1016/j.foar.2013.11.006

[2] Emmanuel, J.B. (2012) "Housing Quality" to the Low Income Housing Producers in Ogbere, Ibadan, Nigeria. Procedia-Social and Behavioral Sciences, 35, 483-494. https://doi.org/10.1016/j.sbspro.2012.02.114

[3] Ugochukwu, I.B. and Chioma, M.I.B. (2015) Local Building Materials: Affordable Strategy for Housing the Urban Poor in Nigeria. Procedia Engineering, 118, 42-49.

[4] Zainal, N.R., et al. (2012) Housing Conditions and Quality of Life of the Urban Poor in Malaysia. Procedia-Social and Behavioral Sciences, 50, 827-838. https://doi.org/10.1016/j.sbspro.2012.08.085

[5] Gopikrishnan, S. and Topkar, V.M. (2017) Attributes and Descriptors for Building Performance Evaluation. HBRC Journal, 13, 291-296. https://doi.org/10.1016/j.hbrcj.2015.08.004

[6] Horayangkura, V. (2012) Incorporating Environment-Behavior Knowledge into the Design Process: An Elusive Challenge for Architects in the 21st Century. Procedia-Social and Behavioral Sciences, 50, 30-41. https://doi.org/10.1016/j.sbspro.2012.08.013

[7] Orihuela, P. and Orihuela, J. (2014) Needs, Values and Post-Occupancy Evaluation of Housing Project Customers: A Pragmatic View. Procedia Engineering, 85, 412-419. https://doi.org/10.1016/j.proeng.2014.10.567

[8] Leaman, A., Stevenson, F. and Bordass, B. (2010) Building Evaluation: Practice and Principles. Building Research \& Information, 38, 564-577. https://doi.org/10.1080/09613218.2010.495217

[9] Mustafa, F.A. (2017) Performance Assessment of Buildings via Post-Occupancy Evaluation: A Case Study of the Building of the Architecture and Software Engineering Departments in Salahaddin University-Erbil, Iraq. Frontiers of Architectural Research, 412-429.

[10] David Jiboye, A. (2012) Post-Occupancy Evaluation of Residential Satisfaction in Lagos, Nigeria: Feedback for Residential Improvement. Frontiers of Architectural Research, 1, 236-243. https://doi.org/10.1016/j.foar.2012.08.001

[11] Forum, W.E. (2016) The Global Gender Gap Report 11. World Economic Forum. http://reports.weforum.org/global-gender-gap-report-2016/economies/\#economy= $\underline{\mathrm{LBR}}$

[12] Husin, H.N., et al. (2015) Correlation Analysis of Occupants' Satisfaction and Safety Performance Level in Low Cost Housing. Procedia-Social and Behavioral Sciences, 168, 238-248. https://doi.org/10.1016/j.sbspro.2014.10.229

[13] Ibem, E.O., et al. (2013) Performance Evaluation of Residential Buildings in Public 
Housing Estates in Ogun State, Nigeria: Users' Satisfaction Perspective. Frontiers of Architectural Research, 2, 178-190. https://doi.org/10.1016/j.foar.2013.02.001

[14] Hashim, A.E., Aksah, H. and Said, S.Y. (2012) Functional Assessment through Post Occupancy Review on Refurbished Historical Public Building in Kuala Lumpur. Procedia-Social and Behavioral Sciences, 68, 330-340. https://doi.org/10.1016/j.sbspro.2012.12.231

[15] Hussein, H. and Jamaludin, A.A. (2015) POE of Bioclimatic Design Building towards Promoting Sustainable Living. Procedia-Social and Behavioral Sciences, 168, 280-288. https://doi.org/10.1016/j.sbspro.2014.10.233

[16] Olanrewaju, A., Anavhe, P. and Hai, T.K. (2016) A Framework for Affordable Housing Governance for the Nigerian Property Market. Procedia Engineering, 164, 307-314. https://doi.org/10.1016/j.proeng.2016.11.624

[17] Dodman, D., et al. (2017) African Urbanisation and Urbanism: Implications for Risk Accumulation and Reduction. International Journal of Disaster Risk Reduction, 26, 7-15. https://doi.org/10.1016/j.ijdrr.2017.06.029

[18] Adeoye, D.O. (2016) Challenges of Urban Housing Quality: Insights and Experiences of Akure, Nigeria. Procedia-Social and Behavioral Sciences, 216, 260-268. https://doi.org/10.1016/j.sbspro.2015.12.036

[19] Shika, S.A., et al. (2012) Developing Post Occupancy Evaluation Sustainability Assessment Framework for Retrofitting Commercial Office Buildings: A Proposal. Procedia-Social and Behavioral Sciences, 65, 644-649.

https://doi.org/10.1016/j.sbspro.2012.11.178 


\section{Appendix 1}

\section{Post Occupancy Evaluation Questionnaire}

Dear respondent,

We are conducting a Post-Occupancy Evaluation research on houses within your housing estate and would appreciate your time answering our questions below. We guarantee you that all information provided us will straightly be kept confidential and use only for academic purpose.

Thanks for taking time from your busy schedule to respond to our questions.

If you have any inquiry regarding this questionnaire, please do not hesitate to contact us at +231776077064 or email: jakezee92@gmail.com

Please mark $(\sqrt{ })$ or answer accordingly where necessary.

\section{A) General}

Please mark the answer appropriate to you.

A1) What is your Gender? 1) Male $\square$ 2) Female

A2) How old are you? 1) 18 - 25 years $\square$ 2) 26 - 35 years

3) 36 - 45 years $\square$ 4) 46 - 60 years $\square$ 5) above 60 years $\square$

A3) How long have you been living in this house? 1) 1 - 3 years $\square$

2) $4-6$ years $\square$ 3) 7 - 10 years

A4) What is your marital status? 1) Marry $\square \quad$ 2) Divorce $\square$ 3) Unmarried 4) Widowed

A5) What is the highest level of education you have attained?

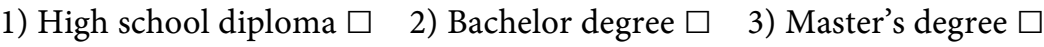

4) $\mathrm{PhD}$ Degree $\square \quad$ 5) Others, please specify

A6) What is your occupation? Please specify

A7) Which sector are you employed in? 1) Public $\square \quad$ 2) Private

A8) How many persons live in this house? 1) 1-Person $\square$ 2) 2-Persons
3) 3-Persons
4) 4 Persons
5) More than 4 persons

A9) What is the range of your monthly income in United States Dollars?
1) $\$ 1-\$ 100$
2) $\$ 101-\$ 200$
3) $\$ 201-\$ 500$
4) $\$ 501$ - $\$ 1000$
5) $\$ 1001-\$ 2000$
6) Above $\$ 2000$

A10) What is the status of your tenure of this house? 1) owned
2) Long term leasing
3) Short term leasing
4) Renting
5) Mortgaging

A11) What was the primary reason that led to your decision to purchase/rent/lease this house? 1) Location $\square$ 2) Price $\square$ 3) Aesthetic
4) Space 5) Quality
6) Accessibility
(7) Others,

pleases pecify 
A12) Which housing estate is your house located? 1) Brewerville, NASSCORP Village $\square \quad$ 2) Fendall Sinlib $\square \quad$ 3) Schiefflin Town (EcoHomes)

A13) There are how many bedrooms in your house? 1) One bed room $\square$

2) Two bedrooms $\square$ 3) Three bedrooms $\square$ 4) Four bedrooms $\square$ 5) Five bedrooms $\square \quad$ 6) More than five bedrooms $\square$

\section{B) Occupants satisfaction with the building attributes}

How satisfied are you with the building attribute of your home? Please mark $(\sqrt{ })$ the answer appropriate to you.

\begin{tabular}{|c|c|c|c|c|c|c|}
\hline No. & Building attributes & Very unsatisfied & Unsatisfied & Neutral & Satisfied & Very satisfied \\
\hline 1 & Sizes of bedrooms & & & & & \\
\hline 2 & Location of bedrooms & & & & & \\
\hline 3 & $\begin{array}{l}\text { Sizes of your livening areas } \\
\text { (Front porch, Living and Dining Rooms? }\end{array}$ & & & & & \\
\hline 4 & $\begin{array}{l}\text { Location of your livening areas } \\
\text { (Front porch, Living and Dining Rooms)? }\end{array}$ & & & & & \\
\hline 5 & $\begin{array}{l}\text { Sizes of your service areas } \\
\text { (Kitchen, Service porch, Store room and Bathrooms }\end{array}$ & & & & & \\
\hline 6 & $\begin{array}{l}\text { Location of your service areas (Kitchen, Service } \\
\text { porch, Store room and Bathrooms }\end{array}$ & & & & & \\
\hline 7 & $\begin{array}{l}\text { Overall how satisfied are you with the general } \\
\text { building layout? }\end{array}$ & & & & & \\
\hline 8 & floor to ceiling height of your home & & & & & \\
\hline 9 & The capacity of your home to meet your overall needs & & & & & \\
\hline 10 & Level of privacy provided by your home & & & & & \\
\hline 11 & The overall aesthetic of the interior of your home & & & & & \\
\hline 12 & The overall comfort of your home & & & & & \\
\hline 13 & The flow of natural light in your home & & & & & \\
\hline 14 & Artificial lightings in your home & & & & & \\
\hline 15 & Natural ventilation across your home & & & & & \\
\hline 16 & The texture of your walls, floor, and ceiling & & & & & \\
\hline 17 & Fixtures in your bathroom(s) and kitchen? & & & & & \\
\hline 18 & $\begin{array}{l}\text { Options to control the indoor temperature of your } \\
\text { home }\end{array}$ & & & & & \\
\hline 19 & The regular smell in your home? & & & & & \\
\hline 20 & Transmission of noise into your home & & & & & \\
\hline 21 & Overall plumbing work within your home & & & & & \\
\hline 22 & Outdoor air quality & & & & & \\
\hline 23 & Disposal of solid and liquid waste from your home & & & & & \\
\hline 24 & The exterior aesthetic of your home & & & & & \\
\hline 25 & $\begin{array}{l}\text { Collection and disposal of runoff water around your } \\
\text { home }\end{array}$ & & & & & \\
\hline 26 & Space between your home and the adjacent homes & & & & & \\
\hline
\end{tabular}




\section{Continued}

27 Green space provided around your home

28 Access to basic services such as shopping centers, hospitals, schools, worship and recreational centers

29 Access to electricity

30 Access to water supply

31 Road access to your home

32 Security provided by your home

33 The option provided you to escape fire emergency

34 Home ability to prevent intrusion from thieves

Home ability to prevent intrusion from animals and insects

36 Home ability to withstand flood?

37 Overall electrical work within your home?

Please state below any other information you may like to share with us:

End of the survey.

We highly appreciate you taking time off your busy schedule to participate in our survey. 


\section{Appendix 2}

Physical assessment form

House No:

Location:

Inspector:

1) What is the typology of this housing unit? 1) Single-family bungalow $\square$
2) Semi detached bungalow
3) Duplex
4) Triplex
5) quadruplex

2) What is the wall material of this unit made of? 1) Refractory bricks

2) Compressed laterite bricks $\square$ 3) Hollow sandcrete blocks $\square$

4) Concrete blocks $\square \quad$ 5) Others please specify

3) What is the wall covering of this house? 1) Refractory bricks finish $\square$

2) Compressed laterite bricks finish $\square$ 3) Mortar screening Emission paint covering $\square$ 4) Mortar screening Enamel paint covering $\square \quad$ 5) $\square$ Ceramic tiles covering

4) What is the type of window install on this unit? 1) Sliding glass
Glaze casement $\square$
3) Timber casemen
4) Jalousie
5) Timber louvers

5) What types of doors are installed on the exterior of this unit? 1) Steel door exterior, timber door interior $\square$ 2) Steel door exterior, plywood door interior $\square \quad 3$ ) Timber door exterior, plywood door interior
4) All plywood
5) All timber

6) Are the inset screens installed on the windows of this unit?

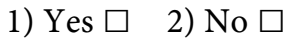

7) Are there steel grills installed on the windows of this unit?

1) Yes $\square$ 2) No $\square$

8) What type of floor finish does this unit have? 1) Granite tiles $\square$
2) Porcelain tiles
3) Ceramic tiles
4) Vinyl tiles

5) Cement screened $\square$

9) What type of ceiling is installed in this unit? 1) Plaster of Paris (POP) screened $\square \quad$ 2) Painted hardboard $\square \quad$ 3) Painted plywood $\square$ 4) Acoustic $\square$

5) Polished timber

10) What is the roofing covering of this unit? 1) Galvanize roofing sheets

$\begin{array}{ll}2) \text { Aluminum roofing sheets } \square & \text { 3) Long span aluminum roofing sheets }\end{array}$

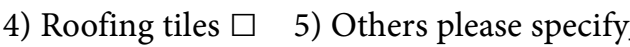

11) What is the current condition of this unit? 1) Excellent $\square$ 2) Good $\square$
3) Needs manor repair
4) Needs repair
5) Needs major repair $\square$

12) What are the buildings layouts like? 1) Well planned
2) Properly layout
3) Condensed $\square$
4) Spacious
5) Disorganized
13) What is the sanitary situation like? 1) Excellent
2) Good

3) Satisfactory $\square$ 4) Fair $\square$ 5) Poor 